\title{
Giant cell tumor of the sternum*
}

\author{
Tumor de células gigantes do esterno \\ Ricardo Alexandre Faria, Carlos Maciel da Silva, José Elias Abrão Miziara, \\ Fernando Yaeda de Melo, Sandra Regina Morini da Silva, Cristiano Ribeiro Viana
}

\begin{abstract}
We report the case of a 74-year-old female patient diagnosed with a giant cell tumor of the sternum. The clinical and radiological presentation was indicative of a primary tumor of the sternum. The patient underwent complementary tests and surgery. The pathological examination confirmed the diagnosis. Commonly observed in the long bones of the appendicular skeleton, this type of tumor is characterized by its local aggressiveness and metastatic potential. We also review the literature on the topic.
\end{abstract}

Keywords: Sternum; Giant cell tumors; Thorax.

\section{Resumo}

Relatamos o caso de uma paciente de 74 anos portadora de tumor de células gigantes em osso esterno. A apresentação clínica e radiológica indicava neoplasia primária de osso esterno. A paciente realizou exames complementares e cirurgia. 0 exame patológico confirmou o diagnóstico. Comumente observado em ossos longos no esqueleto apendicular, esse tipo de tumor caracteriza-se por sua agressividade local e pelo potencial metastático. Também fazemos uma revisão sobre o tema.

Descritores: Esterno; Tumores de células gigantes; Tórax.

\section{Introduction}

Giant cell tumors (GCTs) are tumors of mesenchymal origin characterized by proliferation of multinucleated giant cells, which are similar to osteoclasts, in a mononuclear cell stroma. ${ }^{(1)}$ This type of tumor was first described in 1818 by Sir Astley Cooper. ${ }^{(1)}$ In 1860, Nelaton described the clinical and histological characteristics of GCTs, highlighting their local aggressiveness. ${ }^{(1)}$ The most commonly affected sites are the long bones (in $80 \%$ of cases), typically around the knees (in 75\%). It is rare for GCTs to be found in the axial skeleton (as occurs in only $2 \%$ of cases), and most of the GCTs affecting this region are sacral. ${ }^{(2)}$ Very rarely do GCTs affect the sternum, there having been only a few isolated reports. Most GCTs appear between the third and fourth decades of life, and they are slightly more likely to affect women than men. ${ }^{(2)}$ Pain and swelling are the most common presentations. ${ }^{(2)}$ lmaging studies suggest expansile, lytic lesions that do not involve the cortical bone. ${ }^{(1)}$ As the tumor grows, it penetrates the cortical layer of the bone and causes pain. ${ }^{(2)}$ The diagnosis is confirmed by pathological anatomy. Excisional biopsy can be performed when the tumor diameter is less than or equal to $4 \mathrm{~cm} .^{(2)}$ If the tumor has a greater diameter, incisional biopsy makes it possible to plan the surgical treatment. Although benign, GCTs are unpredictable, the risk of local recurrence being $20-40 \%$ and the risk of pulmonary metastasis being $2 \% .^{(2)}$

\section{Case report}

A 74-year-old White female homemaker sought medical attention. The patient reported having been initially examined at another facility due to a fall from standing height. At the time, the tests revealed a tumor of the sternum. She presented with constant localized pain (without irradiation) that was partially controlled with analgesics. The patient stated that she used

\footnotetext{
* Study carried out at the Cancer Hospital of Barretos, Pio Xll Foundation, Barretos, Brazil. Correspondence to: Ricardo Alexandre Faria. Rua 03, 3595, Jardim Portugal, CEP 13504-091, Rio Claro, SP, Brasil. Tel 5519 3597-9091. E-mail: rickpreto@zipmail.com.br Financial support: None.

Submitted: 14 September 2009. Accepted, after review: 24 May 2010.
} 
hydrochlorothiazide (25 mg/day) for the treatment of systemic arterial hypertension. She reported no recent respiratory infection or previous contacts, nor did she report a personal or family history of cancer. She described herself as a nonsmoker. Physical examination revealed that she was in good general health, with good color, and well as being well hydrated, stable and without changes in the other systems. She had a fixed, fibroelastic tumor, which was painful on palpation, affecting nearly two thirds of the sternum. There was no local phlogosis or evidence of incisional biopsy scarring. The patient provided the result of a pathological examination performed at another facility, the findings of which were suggestive of a brown tumor, which is a type of GCT. At the outpatient clinic of the Cancer Hospital of Barretos, complementary tests (chest CT and biochemical profile) were requested. The biochemical test results (serum levels of phosphorus, parathyroid hormone, and calcium) were normal. A CT scan of the chest revealed a lytic process $(12 \times 7.5 \times 4.5 \mathrm{~cm})$ affecting the cortical layer of the sternum, as well as a nonspecific pulmonary nodule $(8 \mathrm{~mm})$ in the lower lobe of the left lung (Figure 1). The patient underwent surgical resection of the tumor with full-plane oncologic margins (monobloc resection), followed by pulmonary nodule resection and chest wall reconstruction with fascia lata. The surgical specimen showed a bone tumor containing lacunae and scattered areas of hemorrhaging. Macroscopically, the surgical margins were free of disease (Figure 2). The postoperative evolution was favorable, and the patient was discharged on day 6. Definitive pathological examination confirmed GCT, with disease-free margins, and the pulmonary nodule had a necrotic aspect. Outpatient follow-up evaluation revealed that the pain experienced by the patient decreased and there was no disease recurrence as of the fifth postoperative month.

\section{Discussion}

There have been only a few isolated reports of GCTs affecting the axial skeleton. Although typically benign (malignancy rate, 2-8\%), GCTs are locally aggressive. ${ }^{(3,4)}$ In most cases, GCTs occur between the third and fourth decades of life, cases such as the one reported here (occurring in the seventh decade of life) being quite rare. ${ }^{(1)} \ln 81 \%$ of the cases, GCTs affect

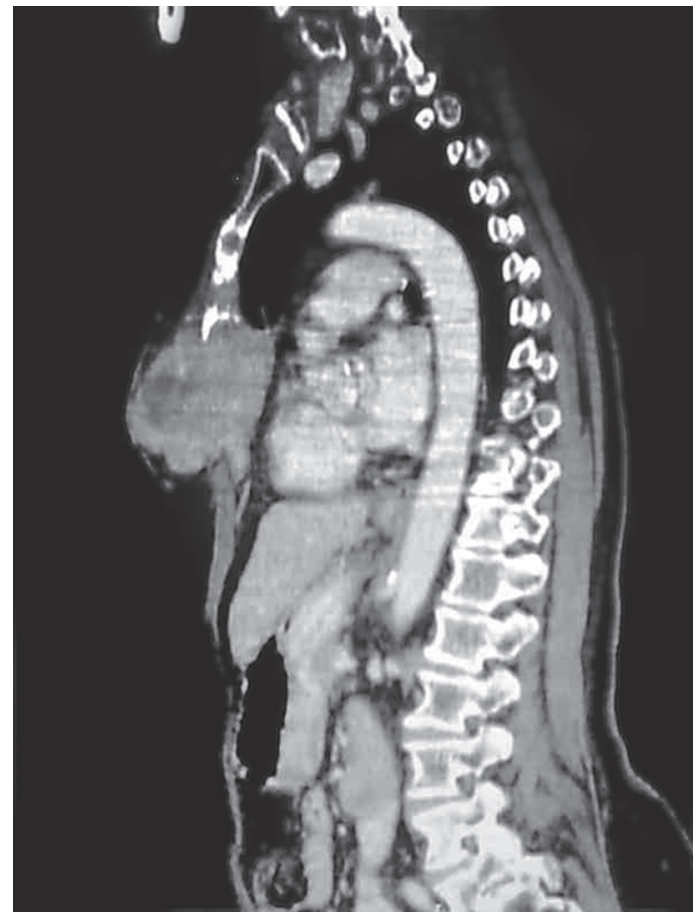

Figure 1 - Chest CT revealing an inflated, eccentric lytic lesion of the sternum, measuring $12 \times 7.5 \times 4.5 \mathrm{~cm}$, with thinning or erosion of the cortical bone.

Whites.(1) The major clinical manifestation is intermittent, localized pain, with or without swelling in the affected region. ${ }^{(1)}$ The duration of the illness varies. ${ }^{(4)}$ Some patients seek treatment

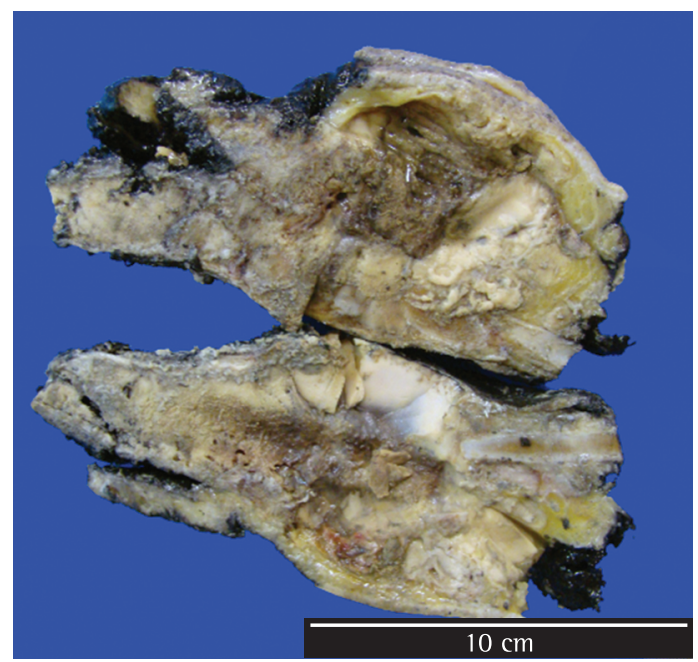

Figure 2 - Macroscopic examination showing a brownish tumor, measuring $10 \times 6 \times 3 \mathrm{~cm}$, with hemorrhagic areas, affecting the sternum, the costal arches, and the adjacent soft tissues, located $3 \mathrm{~cm}$ from the bone margin and tangent to the soft tissue surgical margin. 


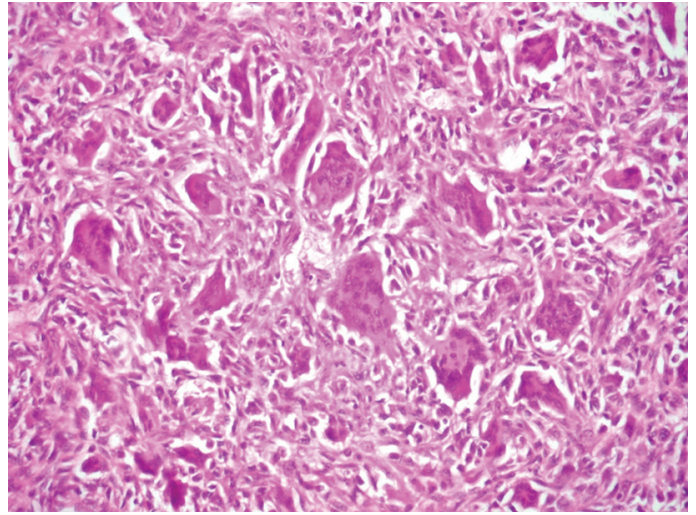

Figure 3 - Photomicrograph showing a tumor composed of multinucleated giant cells in a spindle cell stroma, without atypical mitoses or cellular atypia (magnification, $\times 100$ ).

because of the pain, others seek treatment because of their perception of the tumor or because of pathological fracture, associating the symptom onset with a particular trauma. ${ }^{(1)}$ As shown in the present report, the classical radiological features of GCTs define them as eccentric lytic lesions, with thinning or erosion of the cortical bone..$^{(1)}$ In general, a single bone is affected..$^{(3,5-8)}$ The clinical, radiological, and histological characteristics of GCTs are similar to those of tumors and pseudotumors such as brown tumors of hyperparathyroidism, aneurysmal bone cysts, epiphyseal chondroblastomas, osteoblastomas, and non-osteogenic fibromas. ${ }^{(1)}$ A working diagnosis of brown tumor (associated with hyperparathyroidism) can be confirmed by biochemical changes in serum levels of calcium and phosphorus. ${ }^{(1)}$ In this report, biochemical tests that helped narrow down the list of possible differential diagnoses were requested, obviating the need for other tests. Magnetic resonance imaging is indicated to define the limits of the tumor and its characteristics as a homogeneous solid lesion, which might present areas containing liquid, resulting from tumor necrosis or from mingling with an aneurysmal bone cyst. ${ }^{(3,5-8)}$ On bone scintigraphy images, an area of intense uptake indicates an increase in reactive osteoblastic activity and allows the investigation of other foci. ${ }^{(3)}$ Due to its high cost and the prioritization of patients, this test was not performed in this case. Chest CT, perhaps aided by the anatomical location of the lesion, proved to be sufficient to clarify the lesion characteristics and limits, providing an overall assessment of the pulmonary nodule. Histologically, GCTs consist of giant cells interposed with spiral and ovoid cells (Figure 3). ${ }^{(3)}$ Some authors, in attempts to determine a prognosis, classify GCTs by assigning grades to their different forms, taking in consideration the characteristics of the stroma and the number of giant cells present. ${ }^{(1)}$ The quantity of stroma cells in itself does not indicate whether a tumor is benign or malignant. ${ }^{(1)}$ Some studies call attention to the possible association between chromosomal changes (arm 19q) and the occurrence of GCTs. (7) The behavior of GCTs is unpredictable. ${ }^{(1)}$ There have been reports of malignant transformation of GCTs after radiotherapy.(1) Surgical treatment is the only way to achieve a cure and should therefore be used whenever possible. ${ }^{(3,5-8)}$ The follow-up evaluation of patients submitted to surgery in order to excise a GCT should include radiological imaging of the surgical site and of the lungs..$^{(1)}$

\section{References}

1. Própero JD. Tumor Gigantocelular. In: Própero JD, editor. Tumores ósseos. São Paulo: Rocca; 2001. p. 93-104.

2. Cordeiro SZ, Cordeiro Pde B, Sousa AM, Lannes DC, Pierro GS. Giant cell tumor of the rib occupying the entire hemithorax. J Bras Pneumol. 2008;34(3):185-8.

3. Futani H, Okumura Y, Fukuda Y, Fukunaga S, Hasegawa S, Yoshiya S. Giant cell tumor of the sternum: a case report and review of the literature. Anticancer Res. 2008;28(6B):4117-20.

4. Malawer MM, Helman LJ, O'Sullivan B. Malignant bone tumors. In: DeVita VT, Lawrence TS, Rosenberg SA, editors. DeVita, Hellman, and Rosenberg's Cancer: Principles \& Practice of Oncology, 8th edition. Philadelphia: Wolters Kluwer/Lippincott Williams \& Wilkins; 2008. p. 1828-30.

5. Abate E, Banki F, Hagen JA, Klipfel N. Giant cell tumor of the sternum. Ann Thorac Surg. 2009;88(2):645-7.

6. Imai K, Minamiya Y, Saito H, Kawai H, Ito M, Ogawa J. Giant cell tumor of the sternum. Jpn J Thorac Cardiovasc Surg. 2006;54(9):405-8.

7. Segawa T, Kanamori M, Ohmori K, Nobukiyo M, Nogami S, Kimura T, et al. Giant cell tumor of the sternum: a case report. J Orthop Sci. 2004;9(2):175-7.

8. Sundaram M, Martin SA, Johnson FE, Wolverson MK. Case report 198. Giant cell tumor of manubrium. Skeletal Radiol. 1982;8(3):225-7. 


\section{About the authors}

\section{Ricardo Alexandre Faria}

Thoracic Surgeon. Santa Casa Sisters of Mercy Hospital of São Paulo, São Paulo, Brazil.

\section{Carlos Maciel da Silva}

Thoracic Oncologist. Cancer Hospital of Barretos, Pio XIl Foundation, Barretos, Brazil.

\section{José Elias Abrão Miziara}

Head of the Department of Thoracic Oncology. Cancer Hospital of Barretos, Pio XII Foundation, Barretos, Brazil.

\section{Fernando Yaeda de Melo}

General Surgeon. Santa Casa Sisters of Mercy Hospital of São Paulo, São Paulo, Brazil and Resident in Surgical Oncology. Cancer Hospital of Barretos, Pio Xll Foundation, Barretos, Brazil.

\section{Sandra Regina Morini da Silva}

Pathologist. Cancer Hospital of Barretos, Pio XII Foundation, Barretos, Brazil.

\section{Cristiano Ribeiro Viana}

Pathologist. Cancer Hospital of Barretos, Pio XII Foundation, Barretos, Brazil. 